\title{
IdeAs
}

Idées d'Amériques

$17 \mid 2021$

Villes et culture dans les Amériques

\section{The study of the Americas in Spain: atomized research}

Manuel Alcántara and Asbel Bohigues

\section{OpenEdition}

Journals

Electronic version

URL: https://journals.openedition.org/ideas/10564

DOI: 10.4000/ideas.10564

ISSN: 1950-5701

Publisher

Institut des Amériques

Electronic reference

Manuel Alcántara and Asbel Bohigues, "The study of the Americas in Spain: atomized research", IdeAs [Online], 17 | 2021, Online since 01 March 2021, connection on 03 June 2021. URL: http:// journals.openedition.org/ideas/10564 ; DOI: https://doi.org/10.4000/ideas.10564

This text was automatically generated on 3 June 2021.

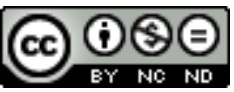

IdeAs - Idées d'Amériques est mis à disposition selon les termes de la licence Creative Commons Attribution - Pas d'Utilisation Commerciale - Pas de Modification 4.0 International. 


\title{
The study of the Americas in Spain: atomized research
}

\author{
Manuel Alcántara and Asbel Bohigues
}

\section{Introduction}

1 Americanism in Spain is deeply divided, along the same line that splits the continent. For obvious reasons, connected with the colonial legacy, Spain has dedicated most of its efforts to studying the so-called Comunidad Iberoamericana formed by the countries that were colonies of Spain and Portugal. It is community-like relationship that based above all on cultural links and also, of course, migration movements and financial flows. The result has been neglect by the academic or intellectual groups dealing with the "Iberian" world of concerns in areas that have a English, French or Dutch past. For this reason, in Spain, it is somewhat difficult to speak in terms of Americanist Studies in a comprehensive.

2 This having been said, the characteristic feature of Americanist Studies in Spain is its institutional atomization. By this we mean that the networks of researchers studying the Americas, from History to Literature, Political Science to Sociology, are not articulated in a centralized institution, with any pre-established patterns or plans for the long-term, as is the case for instance with the Latin American Studies Association (LASA) or the Society for Latin American Studies (SLAS). Neither is there any single institution that regroups them such as in France the Institute des Amériques or the Institute of the Americas in Great Britain

There is the Asociación Española de Americanistas, but its last congress was in 2018 in Castelló, and the next one will be in Santiago de Compostela in 2021. The purpose of this association is the to hold various congresses and symposia year after year and promote activities; nevertheless, its academic focus is exclusively upon History. Since 1982 there was a Consejo Español de Estudios Iberoamericanos (CEIB) that brought together member institutions dealing with Ibero-American social studies, in an effort to coordinate their activities and hold a large conference every two years. The CEIB was a 
member of the Federación Internacional de Estudios de América Latina y el Caribe (FIEALC) and ceased their activities three years ago.

\section{North American and Canadian Studies}

North American studies in Spain deserve special attention, since, once again, there is no such overarching association that groups all Americanist researchers. We must keep in mind too that there is a clear division between Latin American Studies and U.S./ Canadian studies, the latter mostly devoted to Literature.

5 The main associations of North American studies are the Asociación Española de Estudios Anglo-Norteamericanos, with annual conferences since 1977; the Spanish Association for American Studies (SAAS), with biennial conferences and an annual newsletter; HispaUSA, with an emphasis on the Latino community in the U.S. The epicentre of American studies is located at the Franklin Institute at University of Alcalá, founded in 1987. This postgraduate research institution focus is fully devoted to American Studies and Bilingual Education through research projects, scholarships and grants, and its dissemination in its own publications and scientific events.

6 It is also worth mentioning the importance of the Fulbright program in Spain, that has allowed many Spanish scholars to teach, study or research in the U.S. Although not limited to American Studies, the bonding role between the U.S. and Spain of such program cannot be ignored.

7 As for Canadian Studies, its epicentres are the Asociación Española de Estudios Canadienses (AEEC, rather inactive since 2006), the Centro de Estudios Canadienses at University of La Laguna, and Fundación Canadá. Since the creation of the latter in 1998, Fundación Canadá has, for long, cooperated with a number of Spanish institutions, such as Casa de América, Fundación Jiménez Abad, or Canada's embassy to Spain. This cooperation has had, as a result, several seminars, publications and media interventions, as well as over 100 agreements between universities of both countries, with research stays of students and professors from both sides of the Atlantic.

\section{The structuration of Americanism in Spain}

8 Americanist studies in Spain, in general terms, are articulated in four main areas (History, Literature, Social Sciences and Law) each one with a small number of leading universities:

\section{History}

9 History of the Americas in Spain is mainly bounded to the Spanish Colonies, and its epicentres are mostly located in Seville because of the existence there of the Archivo de Indias, a huge archive with official documents of the colonial period. This fact always attracted numerous Spanish and foreign researchers who have contributed to encourage the making the city a highly influential center of research devoted to the colonial era. So, the Escuela de Estudios Hispano-Americanos integrated into the Consejo Superior de Investigaciones Cientificas (CSIC, the Spanish public research institution), and the Instituto Universitario de Estudios sobre América Latina at University of Seville are two 
relevant centres. Besides them, we can consider the Departments of History of America at Complutense University of Madrid (UCM) and at Jaume I University at Castelló, the Instituto Universitario de Investigación en Estudios Latinoamericanos at University of Alcalá, or the Centro Interdisciplinario de Estudios Americanistas at University of Santiago de Compostela. History is also presented in other Spanish universities, but the groups of scholars dedicated to the Americas are small-scale.

\section{Literature}

10 The main representation of Latin Americanist Literature is the Centro de Estudios Literarios Iberoamericanos Mario Benedetti (CEMAB) at University of Alicante. Some other universities with strong dynamic groups of researchers include Salamanca, Seville, Granada and the Autonomous University of Madrid. In this area, there is the Asociación Española de Estudios Literarios Hispanoamericanos. Regarding Nord American literature there are studies at the Universities of Alcalá (Franklin Institute) and Salamanca, and the Biblioteca Javier Coy d'estudis nord-americans in Valencia plays a relevant editorial role.

\section{Social Sciences}

11 (Political Science, Sociology, International Relations, Economy). Its epicentres are located in the Instituto de Iberoamérica at University of Salamanca, the Complutense Universiy of Madrid, and Alcalá de Henares with the IELAT. They have consolidated activities around postgraduate programs, as well as research projects on representative democracy and development economics. The Master's degree Latin America \& Europe in a Global World (LAGLOBE) coordinated by the Universities of Salamanca, Paris and Stockholm, supported by the European Union Erasmus + Program, is the most recent attempt to create and reinforce a network of European Americanists.

\section{Law}

This area is perhaps one of the defining characteristics of the Americanist, namely Latin Americanist, Studies in Spain. The fact that Law in Latin American countries has its foundations in Roman law, the practices themselves emanating during the three centuries of colonial domination, and the fact of sharing the same language, have facilitated a remarkably far-reaching bond between lawyers, judges and professionals of the judiciary of all countries. This includes summer schools that offered specialization courses since the 1990s to lawyers in Salamanca and Toledo, a successful initiative emulated by other Universities in recent years, with hundreds of students every year. The Fundación Jiménez Abad in Zaragoza, sponsored by the regional parliament, offers remarkable programs thanks to the organization of seminars and its editorial line, also coordinating a very active network with Latin American institutions of public law. There are also legal consultant activities organized across the region on legal topics, with the extinct Fundación Centro de Estudios Políticos y Sociales (CEPS) in Valencia as one of its most representative institutions in the last decades.

13 As a result of this ongoing research, these Spanish institutions publish a number of specialized scientific journals in the area of Americanist Studies, such as América Latina 
Hoy, the Anuario de Estudios Americanos, Cuadernos Hispanoamericanos, or Pensamiento Iberoamericano, In addition, Revista CIDOB d'Afers Internacionals, Política Exterior and the publications (working papers, policy papers...) by Fundación Carolina are also noteworthy in these fields, although these latter publications are not specialized exclusively in Americanism, as the former are. In spite of these efforts, the Spanish Academy has little impact beyond national borders in top-ranked journals. In the only five Area Studies JCR Web of Science journals devoted to Latin America, Spanish scholars (one or two names) are present in the editorial boards of just two of these journals.

14 Thus, universities and other scientific or academic institutions have in fact made an effort to institutionalize fields or subfields of Latin/American Studies in research centres or departments. Among the most dynamic, in terms of events, publications, journals, etc. we find the Instituto de Iberoamérica at University of Salamanca, the Latin Americanist group from UCM, the CEMAB in Alicante, and IELAT in Alcalá. Also, the work done by Fundación Carolina is worth noting, especially its fellowship program, although strictu sensu its purpose is slightly different, in that it seeks to reinforce and strengthen Spain-Latin American relations. One should also mention some think tanks, such as Real Instituto Elcano in Madrid, or CIDOB in Barcelona.

There are also a number of organizations and foundations that are situated beyond the strict academic world mostly supported by public funds, like Fundación Internacional y para Iberoamérica de Administración y Políticas Públicas (FIIAPP), Casa de América, CEXECI (since 2017, integrated in the Fundación Academia Europea e Iberoamericana de Yuste), Casa de Colón, the Ibero-American Section of the Ateneo de Madrid, and some other examples. Furthermore, the Programa de Apoyo a la Cooperación y a la Política Iberoamericana (PROCOPI) at AECID (where it remains one of the best libraries in the country on the topic), has been actively participating in Spanish politics toward the region and the Ibero-American Summits, and studies on Civil Society Cooperation in EU countries for the European Commission.

\section{Consolidation and weakening}

1992 was a very relevant year for Americanism in Spain, as the fifth Centenary of the discovery of America was commemorated. This meant that funds from the national science and technology program were earmarked to carry out various activities, but private companies were also involved through their foundations. Collections of Latin American-focused study publications from both public and private bodies were launched. For example, the insurance company Mapfre - Mapfre America Foundation edited a collection with more than a hundred titles; the Institute of Ibero-American Cooperation (official), also published hundreds of titles. Besides that, three institutions played a relevant role on the development of Americanism: AIETI (private) funded research on contemporary topics, mainly focused on international relations and published a well-known journal called Síntesis; the Secretaría General Iberoamericana, as a result of the creation of the annual meeting of Heads of the State Ibero-American Summit, edited a journal, Pensamiento Iberoamericano; and last, but not the least, IRELA, sponsored by the European Parliament, was an analysis and research institute that organized seminars and published numerous working papers. The Instituto de Iberoamérica at University of Salamanca was also created at that time, and this 
University launched a series of studies under the name Library of America. After the 1992 boom, 2000 was a turning point in Spain, with the creation of many of the aforementioned institutions, such as Real Instituto Elcano and Fundación Carolina, as well as new momentum given of the work by AECID. A trend of consolidation, institutionalization actually, was on course.

However, as in many parts of Europe, the budget cutbacks induced by the 2008/9 crisis seriously impacted the scope of American Studies in the country, just as other fields in the Social Sciences. The effects were: non-replacement of retiring researchers; reduced budgets for research projects, participation in congresses, and mobility; the restructuring of departments, from more specialized to more generic, with the consequent loss of identity because a Department of the History of America, with say 10 members, cannot be assimilated to a Department of Contemporary History, with say 30 members. Along the same lines, due to the Bologna process, the Americanist syllabi were reduced too, with a decrease in the offer of courses and lectures.

With such impoverished institutions and faculty, the result has been a rather weakened Americanist Studies offer, although remaining active and dynamic despite the dismal environment, thanks to the work of many individuals and key research centres across the country.

Currently, the main venue for individual researchers to cooperate and develop research networks is via research projects, funded by the Spanish Government. Nevertheless, these are perennial groups, rooted and stable over time, since they are limited both in time (up to 3 years) and in self-funding.

\section{Conclusion}

This piece does not purport to propose an exhaustive list of Spanish organizations devoted to studying the Americas. We acknowledge that there is a long list of institutes, centres, departments, and especially individual researchers, whose ardent work over the years has made meaningful contributions to more scholarly, interdisciplinary understanding of the region. However, what needs to be emphasized is the absence of an all-inclusive Spanish institution exclusively devoted to American studies. Both the Spanish Academy and Americanism would have much to gain from such an institution.

\section{AUTHORS}

\section{MANUEL ALCÁNTARA}

Manuel Alcántara is Full Professor at the University of Salamanca, Spain and Visiting Professor at UPB in Medellin, Colombia. His field research concerns Parliament Elites, Political Parties and Elections in Latin America. His most recent books include Presidents and Democracy in Latin America (2018), Politics and Political Elites in Latin America. Challenges and Trends (2020) and El oficio de político (2020, 2nd edition) 


\section{ASBEL BOHIGUES}

Asbel Bohigues holds a PhD in Political Science from the University of Salamanca (2019), with visiting stays at University of Pittsburgh and Ludwig-Maximilians University of Munich. He is currently assistant professor of Comparative Politics at IUNIT, and assistant editor of América Latina Hoy and Revista Latinoamericana de Opinión Publica. His research focuses on comparative politics, elites and democracy, with a regional specialization in Latin America. His work has been published in Revista Brasileira de Política Internacional, Bulletin of Latin American Research, and Revista de Ciencia Política among others. 